\title{
PENYELENGGARAAN MADRASAH DI DAERAH MINORITAS MUSLIM
}

\section{OPERATION OF MADRASAH IN REGIONS WITH FEW MOSLEMS}

\author{
Umul Hidayati \\ Puslitbang Pendidikan Agama dan Keagamaan, \\ Badan Litbang dan Diklat, Kementerian Agama RI, \\ Jln M.H. Thamrin No. 06 Jakarta, Gedung Lt. 19. \\ Email: hidayatikuncoro@yahoo.com
}

\begin{abstract}
The study aims to know the existence of operation of madrasah in regions with few moslems in Manokwari Regency, West Papua Province. Using qualitative method, the study result shows that the operation of madrasah in the study location is initiated by migrant people from outside Papua. All madrasahs there are operated in Transmigration settlements and in Hidayatullah pesantren. If we see eight components of education, the madrasahs generally have not met the SNP. From the government policy, the madrasahs have not gained equal treatment from the regional government and the regional parliament due to political, socio cultural, religious and ethnicity factors while the policy of the ministry of religion still refers to the government's policy through the Central Government's Performance Plans not realized in accordance with the region's need. The relationship between the madrasahs and the migrant people is good as the people need comprehensive Islamic educational service and formal education is yet available in their settlements. However, the relationship with indigenous people is hampered by regulations imposed on migrants that sometimes bring loss.
\end{abstract}

Keywords: operation, madrasah, Muslim minority

\begin{abstract}
Abstrak
Penelitian ini bertujuan untuk mengetahui eksistensi penyelenggaraan madrasah di daerah minoritas muslim di Kabupaten Manokwari, Propinsi Papua Barat. Dengan menggunakan metode kualitatif, hasil penelitian menunjukkan bahwa penyelenggaraan madrasah di lokasi penelitian dilatarbelakangi kedatangan masyarakat migran dari luar Papua. Seluruh madrasah di sana berdiridi lokasi Pemukiman Transmigrasi dan di lingkungan pondok pesantren Hidayatullah. Dilihat dari kondisi delapan komponen pendidikan, umumnya madrasah tersebut belum memenuhi SNP. Dilihat dari kebijakan pemerintah, madrasah belum memperoleh kebijakan yang berkeadilan dari Pemda maupun DPRD, yang disebabkan oleh faktor politik, sosial budaya, agama dan etnis. Sedangkan kebijakan Kemenag sendiri masih mengacu pada kebijakan pusat melalui Rencana Kinerja Pusat (RKP) yang terkadang realisasinya tidak sesuai dengan kebutuhan daerah. Hubungaan madrasah dengan masyarakat migran cukup baik, karena pendirian madrasah memang dikehendaki oleh masyarakat tersebut, karena masyarakat sangat membutuhkan layanan pendidikan agama Islam yang utuh dan layanan pendidikan formal yang memang belum tersedia di sekitar pemukiman mereka. Namun hubungan dengan masyarakat penduduk asli, terkendala dengan aturan-aturan yang berlaku yang juga diterapkan pada penduduk pendatang yang terkadang merugikan.
\end{abstract}

Kata Kunci: penyelenggaraan, madrasah, minoritas Muslim

Naskah diterima 27 Juni 2015. Revisi pertama, 14 Juli 2015. Revisi kedua, 20 Juli 2015 dan revisi terahir 29 Juli 2015 


\section{PENDAHULUAN}

Setiap warga negara (termasuk yang berada di daerah atau komunitas adat terpencil, terbelakang, di daerah konflik, bencana alam, bencana sosial dan tidak mampu dari segi ekonomi), mempunyai hak yang sama untuk memperoleh pendidikan yang bermutu dan melalui layanan khusus. ${ }^{1}$ Implikasi dari undang-undang ini, negara berkewajiban membangun akses pendidikan yang layak bagi seluruh warga negara dimanapun berada dan dalam kondisi apa pun, meskipun merupakan kelompok minoritas, karena perbedaan suku, ras, agama, sosial, politik dan lainnya.

Dalam rangka pemenuhan layanan pendidikan tersebut, pemerintah khususnya Kemenag selama ini telah memperbaiki dan membenahi penyelenggaraan pendidikan madrasah yang tumbuh dari masyarakat dan tersebar di seluruh pelosok tanah air, tak terkecuali di daerah-daerah minoritas muslim. Namun kita sadari bahwa begitu massifnya pertumbuhan madrasah, dan begitu gencarnya Kemenag melakukan pembenahan, masih banyak madrasah yang masih memiliki kualitas rendah.

Kondisi madrasah tersebut dapat dilihat dari penelitian tentang Standar Nasional Pendidikan (SNP), ${ }^{2}$ menunjukkan bahwa madrasah belum memenuhi SNP secara maksimal dengan tingkat keterpenuhan

1 Ditegaskan dalam Undang-Undang Nomor 20 Tahun 2003 tentang Sistem Pendidikan Nasional Pasal 5, ayat 1 dan ayat 3

${ }^{2}$ Hasil Penelitian Puslitbang Pendidikan Agama dan Keagamaan. 2009. "Kesiapan Madrasah dalam Pemenuhan Standar Nasional Pendidikan (Standar Pengelolaan Pendidikan oleh Satuan Pendidikan, Standar Pendidik dan Tenaga Kependidikan serta Standar Sarana Prasarana) di MTsN".
$62 \%$ di bidang sarana prasarana dan 64\% di bidang pengelolaan. Di bidang ketenagaan, hasil penelitian, ${ }^{3}$ menunjukkan bahwa kompetensi kepala MA pada aspek kepemimpinan, administrasi dan supervisi masih rendah. Sedangkan hasil penelitian tentang Kompetensi GPAI MTs, ${ }^{4}$ menunjukkan bahwa kompetensi sosial, kepribadian dan paedagogikguru cukupbaik, namun kompetensi profesionalnya kurang baik. Hasil penelitian tentang kompetensi guru mapel umum, ${ }^{5}$ menunjukkan bahwa kompetensi profesional dan paedagogik guru masih rendah. Sedangkan hasil penelitian tentang Kompetensi Kepala MA, ${ }^{6}$ menunjukkan bahwa kompetensi kewirausahaan rendah dan masuk kategori kurang baik. Di bidang pelaksanaan pembelajaran, penelitian tentang Pemenuhan SNP, hasilnya menunjukkan bahwa MTsN belum memenuhi SNP dan masuk kategori kurang memenuhi, dengan tingkat keterpenuhan 58\% untuk Standar Proses; 60\% untuk Standar Isi; 54\% untuk Standar Penilaian dan 50\% untuk Standar Kompetensi Lulusan. ${ }^{7}$

Beberapa hasil penelitian ini menunjukkan bahwa madrasah secara umum belum memenuhi SNP dan masih memiliki

${ }^{3}$ Hasil Penelitian Puslitbang Pendidikan Agama dan Keagamaan. 2004. "Kompetensi Kepala Madrasah Aliyah (MA)".

${ }^{4}$ Hasil Penelitian Puslitbang Pendidikan Agama dan Keagamaan. 2005. "Profil Kompetensi guru PAI MTs".

${ }^{5}$ Hasil Penelitian Puslitbang Pendidikan Agama dan Keagamaan. 2007. "Kompetensi Guru Mapel Umum (Matematika, IPA dan Bhs Ingris) MTs”.

${ }^{6}$ Hasil Penelitian Puslitbang Pendidikan Agama dan Keagamaan. 2011. "Kompetensi Kepala MA".

${ }^{7}$ Hasil Penelitian Puslitbang Pendidikan Agama dan Keagamaan. 2010. "Pemenuhan Standar Nasional Pendidikan (Standar Proses, Isi, Penilaian dan Kompetensi Lulusan) di MTsN". 
kelemahan dalam berbagai aspeknya. padahal madrasah-madrasah ini merupakan madrasahyang berada di daerah-daerahyang tidak marginal. Bagi madrasah-madrasah yang berada di daerah marginal khususnya di daerah minoritas muslim, tentu memiliki permasalahan yang jauh lebih komplek dan rumit, tidak hanya terbatas pada kondisi fisik, tetapi juga kondisi non fisik seperti rendahnya daya dukung masyarakat dan pemerintah.

Diberlakukannya peraturan otonomi daerah, dimana pemerintah daerah memiliki kewenangan yang sangat besar dalam mengatur anggaran termasuk mengatur anggaran pendidikan. ${ }^{8}$ Menurut Azyumardi Azra, ${ }^{9}$ pemberlakuan otonomisasi/desentralisasi pendidikan telah menimbulkan implikasi bagi pendidikan Islam (termasuk madrasah), karena desentralisasi pendidikan tidak melibatkan lembaga-lembaga pendidikan Islam termasuk madrasah, namun ia harus mengikuti perubahan tersebut.

Bagi madrasah yang berada di daerah minoritas muslim, kondisi ini tentu saja tidak menguntungkan, karena berbagai posisi penting di Pemerintah Daerah yang diduduki oleh orang-orang dari kelompok mayoritas (non muslim) tentu akan sangat kecil kemungkinannya memiliki perhatian

${ }^{8}$ Undang-undang Nomor 22 Tahun 1999 Tentang Otonomi Daerah yang kemudian direvisi dengan Undang-undang Nomor 32 tahun 2004 pasal disebutkan 7 bahwa "kewenangan daerah mencakup kewenangan dalam seluruh bidang pemerintahan, kecuali kewenangan dalam bidang politik luar negeri, pertahanan keamanan, peradilan, moneter dan fiskal dan agama..

9 Azyumardi Azra. 2002. Paradigma Baru Pendidikan Nasional (Rekontruksi dan Demokratisasi), Kompas, Jakarta. h. 3 terhadap madrasah, sehingga kebijakankebijakan yang dikeluarkan akan sangat deskriminatif dan kurang atau bahkan tidak pernah menyentuh madrasah. Menurut Suaedy dkk bahwa kelompok minoritas merupakan kelompok paling rentan menjadi korban tindakan intoleransi, diskriminasi, hingga aksi kekerasan. Di Indonesia kelompok minoritas masih mengalami masalah serius mencakup tiga hal tersebut. ${ }^{10}$ Kebijakan yang deskriminatif ini semakin kuat, manakala Pemerintah Daerah masih salah tafsir dalam memahami peraturan Mendagri ${ }^{11}$ yang sebenarnya tidak melarang Pemda memberikan bantuan pada madrasah.

Di samping persoalan deskriminasi, partisipasi masyarakat juga merupakan masalah terbesar yang dihadapi madrasah pasca diberlakukannya otonomi daerah. ${ }^{12}$ Apalagi Kemenag sendiri selaku instansi pemerintah yang menaungi madrasah tidak memiliki penganggaran memadahi bagi penyelenggaraan madrasah, sehingga sulit merealisasikan anggaran dengan asas keadilan dan pemerataan dan terjadi perlakuan yang berbeda antara madrasah

${ }_{10}$ Ahmad Suaedy dkk. 2012. Islam dan Kaum Minoritas: Tantangan Kontemporer, Jakarta: The Wakhid Institue, h. i

${ }^{11}$ Surat Keputusan Mendagri Nomor 903/2429/ SJ Tahun 2006 Tentang Pedoman Penyusunan APBD, yang ditafsirkan SK tersebut tidak memperkenankan pengalokasian anggaran untuk membantu institusi vertikal dalam melaksanakan tugas dan fungsinya. Padahal tahun berikutnya Mendagri telah merubah kebijakannya dengan memperbolehkan Pemerintah Daerah mengalokasikan anggaran APBD-nya untuk kegiatan pendidikan keagamaan (madrasah), yang penyalurannya dilakukan melalui Dinas Pendidikan setempat yang dituangkan dalam Rancana Anggaran Satuan Kerja (RASK) Perangkat Kerja Daerah

${ }^{12}$ Masyarakat Pendidikan. 2002. Madrasah di Era Otonomi dan Globalisasi, Vol. I Nomor 5, Maret-April, h. 11 
negeri dan swasta, antara madrasah perkotaan dan madrasah pedesaan, dan antara madrasah di daerah mayoritas muslim dan madrasah di daerah minoritas muslim.

Untuk mengetahui bagaimana kondisi riil penyelenggaraan madrasah di daerahdaerah minoritas muslim, maka pada tahun 2014 Puslitbang Pendidikan Agama dan Keagamaan melakukan penelitian berjudul "Penyelenggaraan Madrasah di Daerah Minoritas Muslim. Penelitian ini penting dilakukan, mengingat banyak madrasah berdiri di daerah minoritas muslim, namun eksistensi penyelenggaraannya belum maksimal, yang disebabkan oleh banyak faktor antara lain: kebijakan penganggaran Kementerian Agama yang belum memprioritaskan madrasah-madrasah di daerah minoritas muslim; sempitnya struktur organisasi Kementerian Agama di daerah minoritas muslim khususnya yang menangani madrasah berakibat pada terbengkalainya penyelesaian berbagai persoalan mdrasah; adanya deskriminasi kebijakan pemda terhadap madrasah; keterlibatan/ daya dukung masyarakat yang belum maksimal; belum dimilikinya sumber-sumber pendanaan mandiri oleh madrasah dan lain sebagainya.

Rumusan permasalahan penelitian ini adalah bagaimana eksistensi penyelenggaraan madrasah di daerah minoritas muslim dilihat dari kondisi umum daerah sekitar madrasah; sejarah berdirinya madrasah; kondisi delapan komponen SNP madrasah; kebijakan pemerintah (Pemda. DPRD, Kemenag); relasi dan lingkungan sosial masyarakat sekitar madrasah, faktor Pendukung dan penghambat

\section{Kerangka Konseptual}

\section{Pengertian Daerah Marjinal}

Daerah marjinal merupakan suatu wilayah yang berada di pinggiran dan dalam kondisi tidak menguntungkan. ${ }^{13}$ Sehingga masyarakat marjinal sering disebut sebagai masyarakat pinggiran, dimana salah satu ciri khasnya adalah tidak terperdaya/ terpinggirkan dalam mendapatkan akses ekonomi, pendidikan, sosial budaya, agama, yang menyebabkan timbulnya pemiskinan struktural, kebodohan dan keterbelakangan. ${ }^{14}$ Menurut Paulo Freire, kaum marjinal dibedakan dalam dua kelompok. Pertama, kelompok yang kurang beruntung, tidak mendapatkan pendidikan yang memadai, tidak mendapatkan kesejahteraan dan terasing dari lingkungan sosial, tereklusi dari sistem sosial orangorang pada umumnya, yang disebabkan karena kondisi fisiknya, seperti penyandang cacat. Kedua, kelompok yang sama dengan kelompok pertama, namun disebabkan karena perbedaan suku, agama, ras (sara), kondisi lingkungan sosialnya, seperti masyarakat di daerah terpencil, suku terasing, perbedaan etnis, warna kulit, agama, budaya, anak-anak yang hidup di jalanan, orang-orang miskin dan terbiasa dengan kekerasan. ${ }^{15}$

${ }^{13}$ Tim Media, Kamus Lengkap Bahasa Indonesia, Media Center, h. 364

14 Djamaludin Djawu, dalam http://jamalmerdeka.blogspot.com/2012/10/apa-itu-kaummarjinal-marginal.html. Diunduh tanggal 8 Pebruari 2014

${ }^{15}$ Paulo Freire. 2002. The Politic of Education; Culture, Power and Liberation, dalam Agung Prihantoro dan Fuad Arif Fudiyar (ed), Politik Pendidikan, Kebudayaan dan Pembebasan, Jogjakarta: Read, hal. 64 . 
Dari uraian tersebut, maka yang disebut daerah marjinal adalah suatu daerah yang didalamnya terdapat suatu kelompok masyarakat yang terpinggirkan yang disebabkan antara lain oleh kondisi fisiknya yang cacat, kondisi ekonominya yang kurang mampu, adanya perbedaan ras, suku, agam dan budaya. Dalam penelitian ini, yang dimaksud daerah marjinal adalah daerah minoritas muslim, yaitu daerah yang di dalamnya terdapat kelompok masyarakat yang terpinggirkan/terabaikan dari pelayanan pendidikannya, yang disebabkan karena perbedaan keyakinan/ agama khususnya penganut agama Islam. Dalam kontek penelitian ini, bagaimana penyelenggaraan madrasah di daerah tersebut, apakah sudah memperoleh perhatian yang baik dari Pemerintah atau belum. Selanjutnya bagaimana daya dukung masyarakat sekitar terhadap madrasah, serta faktor pendukung dan penghambatnya.

\section{Pengertian Daerah Minoritas Keagamaan}

Minoritas (minority) adalah golongan sosial yang jumlah warganya lebih sedikit dibandingkan dengan golongan lain. ${ }^{16}$ Minoritas, adalah kelompok penduduk di sebuah negara yang berbeda dengan kebanyakan penduduk negara itu, yang disebabkan karena perbedaan agama, mazhab, keturunan, bahasa dan perkaraperkara dasar lainnya. Contoh, minoritas Kristen di Mesir, Syria dan Iraq. Minoritas Yahudi di Maroko dan Iran. Minoritas muslim di negara-negara Barat. ${ }^{17}$ Kelompok minoritas

${ }^{16}$ Tim Media, op Cit., h. 374

${ }^{17}$ Syaefany dalam makalahnya berjudul "Minoritas Muslim Dan Permasalah Mereka Dari Sudut Hukum Fiqh (Fiqh Aqalliyat)", dalam http://syaf.blogspot. (minority groups) adalah kelompok-kelompok yang diakui berdasarkan perbedaan ras, agama, suku, bangsa, yang mengalami kerugian sebagai akibat prasangka (prejudice) atau diskriminasi. ${ }^{18}$ Istilah minoritas (minoritie) dalam peradaban Barat adalah masyarakat yang memiliki identitas budaya yang berbeda dengan identitas budaya masyarakat mayoritas. Dalam khasanah Islam/keagamaan, minoritas dilihat dari segi kwantitatif, yakni memandang perbedaan karena jumlah. ${ }^{19}$ Sedangkan kaum minoritas, dalam retorika antar bangsa disebut the minorities atau minority groups, yang merujuk kepada kelompok masyarakat yang jumlahnya lebih sedikit dibanding kelompok masyarakat lain yang dominan. Pengelompokkan ini dilakukan atas dasar perbedaan agama, ras, bahasa, paham politik, asal usul daerah, kelas sosial ekonomi, dan perbedaan dalam pendapat. ${ }^{20}$

Dari uraian tersebut, maka yang dimaksud daerah minoritas adalah suatu tempat/daerah dimana terdapat kelompokkelompok masyarakat yang jumlahnya lebih sedikit dibandingkan kelompok masyarakat daerah tersebut karena perbedaan agama, $\underline{\text { ras, }} \underline{\text { bahasa, }}$ paham politik, asal usul daerah, kelas sosial ekonomi ataupun perbedaan dalam pendapat. Dalam penelitian ini, yang

com/2012/03/minoritas-muslim-dan-permasalahmereka. html. diunduh tanggal 10 Pebrauri 2014

18 Isnaini dalam http://issnaini.blogspot. com/2012/10/makalah-diskriminasi-pendidikan. html. diunduh tanggal 10 Pebruari 2014

${ }^{19}$ Ulya Fikriyanti dalam makalahnya berjudul "Dilema kaum Minoritas : Islam Solusi Tepat" dalam http://www.academia.edu/3769057/KelompokSesial-Mayoritas-dan-Minoritas. diunduh tgl 10 Pebruari 2014

20 http://www.academia.edu/3769057/ Kelompok-Sesial-Mayoritas-dan-Minori tas. diunduh tanggal 10 Pebruari 2014. 
dimaksud dengan daerah minoritas adalah daerah minoritas keagamaan khususnya minoritas muslim yaitu suatu tempat/daerah dimana terdapat kelompok masyarakat muslim yang jumlahnya lebih sedikit dibandingkan dengan kelompok masyarakat penganut agama lain di daerah tersebut.

\section{Pengertian Madrasah}

Kata "madrasah" berasal dari akar kata 'darasa' yang memiliki makna sebagai 'keterangan tempat' Secara harfiah 'madrasah' merupakan 'tempat belajar' atau 'tempat untuk memberikan pelajaran'. Dalam bahasa Indonesia, diartikan sebagai 'sekolah', meskipun kata 'sekolah' itu sendiri berasal dari dari bahasa asing 'school. ${ }^{21}$ Dalam pengertian lebih luas, madrasah berarti tempat proses belajar mengajar yang dilakukan secara terarah, terpimpin dan terkendali, yang menggambarkan proses pembelajaran formal sebagaimana sekolah, namun memiliki spesifikasi/karakteristik yakni bertumpu pada substansi ajaran Islam. ${ }^{22}$

Dalam perkembangannya, madrasah telah mengalami berbagai perubahan yakni dari sistem pesantren ke madrasah; dari metode tradisional ke klasikal; dari sistem halaqah ke bangku, meja dan papan tulis; dari kurikulum tradisional ke modern; dari pendidikan klasik ke pembaharuan pendidikan yang modern. ${ }^{23}$ Saat ini, madrasah

21 Haidar Putra Daulay. 2005. Historisitas dan Eksistensi (Pesantren, Sekolah dan Madrasah), Yogyakarta: PT. Tiara Wacana, h. 59.

${ }^{22}$ Masykuri dkk. 2005. Profil Madrasah Tsanawiyah, Jakarta : Departemen Agama RI, Direktorat Jenderal Kelembagaan Agama Islam, h. 2.

${ }^{23}$ Badri Yatim dkk. 2000. Sejarah Perkembangan Madrasah, Jakarta : Departemen Agama RI Direktorat Jenderal Pembinaan Kelembagaan Agama Islam, h.198. merupakan sekolah umum sebagaimana disebutkan dalam undang-undang bahwa pendidikan dasar berbentuk Sekolah Dasar (SD) dan Madrasah Ibtidaiyah (MI) atau bentuk lain yang sederajat serta Sekolah Menengah Pertama (SMP) dan Madrasah Tsanawiyah (MTs) atau bentuk lain yang sederajat, sedangkan pendidikan menengah berbentuk Sekolah Menengah Atas (SMA) dan Madrasah Aliyah (MA). ${ }^{24}$ Dalam Permenag disebutkan bahwa "madrasah" adalah satuan pendidikan formal dalam binaan Menteri Agama yang menyelenggarakan pendidikan umum dan kejuruan dengan kekhasan agama Islam yang mencakup Raudatul Athfal, Madrasah Ibtidaiyah, Madrasah Tsanawiyah, Madrasah Aliyah dan Madrasah Aliyah Kejuruan. ${ }^{25}$ Dari uraian tersebut, maka madrasah yng dimaksud dalam penelitian ini adalah satuan lembaga pendidikan formal tingkat dasar (Madrasah Ibtidaiyah dan Madrasah Tsanawiyah) dan tingkat atas (Madrasah Aliyah) yang dibawah pembinaan Menteri Agama.

\section{Pengertian Penyelenggaraan}

Penyelenggaraan adalah mengadakan, mengurus dan mengusahakan sesuatu sepertimemeliharadanmerawat, melakukan perintah atau rencana, menunaikan atau menyampaikan (maksud, cita-cita, harapan, tugas kewajiban) untuk tujuan tertentu. ${ }^{26}$ Dalam kaitannya dengan penyelenggaraan madrasah, maka penyelenggaraan disini adalah kegiatan yang dimulai sejak dari

${ }^{24}$ Undang-undang Nomor 20 Tahun 2003, Op Cit, pasal 18 ayat (3).

${ }^{25}$ Peraturan Menteri Agama Republik Indonesia Nomor 90 Tahun 2013 tentang Penyelenggaraan Pendidikan Madrasah Bab I Pasal 1 ayat 2

${ }^{26}$ Tim Media, Op Cit, h. 374 
perencanaan, pendirian, hingga pelaksanaan proses dan pencapaian hasil serta evaluasi. Bagaimana sejarah pendirian, pengelolaan, upaya-upaya dalam mempertahankan eksistensi dan pengembangan madrasah, bagaimana melakukan kerjasama dengan pihak lain, meningkatkan mutu, memperbaiki kekurangan dsb.

Dalam Permenag ${ }^{27}$ disebutkan bahwa penyelenggaraan pendidikan madrasah adalah kegiatan pelaksanaan komponen sistem pendidikan pada Raudatul Athfal, Madrasah Ibtidaiyah, Madrasah Tsanawiyah, Madrasah Aliyah dan Madrasah Aliyah Kejuruan, agar proses pendidikan dapat berlangsung sesuai dengan tujuan pendidikan nasional. Pendirian madrasah diselenggarakan oleh pemerintah dan masyarakat. Pendirian madrasah yang diselenggarakan oleh pemerintah ditetapkan oleh meneteri. Sedangkan pendirian madrasah yang diselenggarakan oleh masyarakat dilakukan oleh Kantor Wilayah atas nama menteri dalam bentuk izin operasional, yang diberikan berdasar kelayakan pendirian. Pendirian madrasah oleh pemerintah wajib memenuhi Standar Nasional Pendidikan. Sedangkan pendirian madrasah oleh masyarakat wajib memenuhi persyaratan administrasi, teknis dan kelayakan pendirian.

Persyaratan administrasi meliputi: 1) penyelenggara pendidikan merupakan organisasi berbadan hukum; 2) memiliki struktur organisasi, AD/ART dan pengurus; 3) mendapat rekomendasi dari Kepala Kantor Kementerian Agama; dan 4) memiliki kesanggupan untuk membiayai penyelenggaraan pendidikan paling sedikit untuk satu (1) tahun berikutnya. Persyaratan teknis meliputi: 1) kesiapan melaksanakan

${ }^{27}$ Op. Cit Peraturan Menteri Agama ......, pasal 7 dan 8 ayat 1, 2 dan 3 dan pasal 9 ayat 1,2,3 dan 4 kurikulum; dan 2) jumlah peserta didik, 3) jumlah dan kualifikasi pendidik dan tenaga kependidikan; 4) kelengkapan sarana prasarana; 5) 6) rencana pembiayaan; 7) pembelajaran (proses pembelajaran, sistem evaluasi, program pendidikan, 8) organisasi dan manajemen pendidikan. Sedangkan persyaratan kelayakan meliputi: 1) tata ruang, geografis, ekologis; 2) prospek pendaftar; 3) sosial dan budaya; dan 4) demografi anak usia sekolah dan ketersediaan lembaga pendidikan formal.

Dari uraian ini, maka yang dimaksud dengan penyelenggaraan madrasah adalah bagaimana pendirian madrasah dilakukan, bagaimana pengelolaannya, proses belajarnya, upaya-upaya pengembangannya, bagaimana mempertahankan eksistensinya, peningkatan mutunya, evaluasinya, kendala dan hambatannya, solusinya, bagaimana memperbaiki kekurangannya dsb. Beberapa hal tersebut yang digali dalam penelitian terkait dengan penyelenggaraan madrasah di daerah minoritas minoritas muslim.

\section{Metodologi Penelitian}

Penelitian berjudul "Penyelenggaraan Madrasah di Daerah Minoritas Muslim" dilaksanakan di Kabupaten Manokwari, Propinsi Papua Barat. Sasaran penelitiannya adalah madrasah (MI, MTs, MA) yang ada di Kabupaten Manokwari. Adapun metode yang digunakan dalam penelitian adalah metode kualitatif. Sedangkan pendekatannya adalah pendekatan fenomenologi yaitu berusaha memahami arti dari peristiwa dan kaitankaitannya terhadap orang-orang biasa dalam situasi-situasi tertentu. ${ }^{28}$ Penelitian

28 Lexy J. Moleong. 2002. Metode Penelitian Kualitatif, Bandung: Remaja Rosdakarya, 2002, Cet. Ke. 16, hlm. 9. 
juga menggunakan pendekatan sosio historis, emik dan etik. ${ }^{29}$

Instrumen utama dalam penelitian adalah peneliti sendiri yang berperan sebagai human instrumen. Adapun sumber data penelitian berupa kata-kata dan tindakan orang yang diamati atau yang diwawancarai sebagai sumber data utama (data primer), selebihnya berupa dokumen sebagai data pendukung (data sekunder). Sumber data dipilih secara purposive dan jumlahnya disesuaikan dengan informasi yang dibutuhkan. Sumber data dimaksud adalah narasumber (responden) yang dianggap kompeten untuk memberikan informasi yaitu kepala dan guru madrasah serta bagian tata usaha sebagai key informan, ketua/pengurus yayasan, komite madrasah, tokoh masyarakat, pengguna (user), pejabat Kemenag, Pemda, Dinas Dikbud, anggota

${ }^{29}$ Apabila seseorang akan menguraikan perilaku manusia, ada dua titik tolak yang dianut yang bermanfaat menurut situasi tertentu yang dalam kajian ilmiah disebut dengan istilah pendekatan emik dan etik. Pendekatan emik dan etik sebenarnya lebih populer di bidang antropologi. Pendekatan emik adalah pengungkapan sistem prilaku manusia bersama satuan strukturnya dan kelompok struktur satuan-satuannya. Pendekatan ini merupakan satu usaha untuk mengungkapkan dan menguraikan pola suatu bahasa atau kebudayaan tertentu yang berkaitan dengan lainnya dalam melakukan fungsi sesuai dengan pola tersebut. Sementara pendekatan etik adalah sebaliknya yakni mengelompokkan secara sistematis terhadap data yang dapat dibandingkan, menyediakan perangkat untuk mengklasifikasikan setiap unsur data; mengorganisasikan data yang telah diklasifikasikan ke dalam tipe-tipe tertentu dan mempelajari, menemukan, menguraikan setiap data baru ke dalam kerangka sistem yang telah dibuat sebelum mempelajari data yang ditemukan. Dengan kata lain pendekatan etik adalah kumpulan rumit antara tujuan dan prosedur yang dikembangkan oleh peneliti. (Lexy J. Moleong (2002): Metode Penelitian Kualitatif, Bandung: Remaja Rosdakarya, 2002, Cet. Ke. 16, hlm. 53-54).
DPRD dan informan lain yang dianggap penting.

Pengumpulan data dilakukan dengan menggunakan teknik wawancara mendalam (in-depth interview), studi dokumen, dan trianggulasi. Sedangkan analisis data menggunakan teknik deskriptif kualitatif. Metode berpikir yang penulis gunakan untuk menganalisis data adalah metode induktif yaitu berangkat dari hal-hal yang bersifat khusus kemudian ditarik fakta yang bersifat umum, dianalisis, dideskripsikan dan ditarik kesimpulan secara umum.

\section{Keterbatasan Penelitian}

Sebenarnya banyak permasalahan yang dapat digali dalam penelitian ini, namun karena adanya keterbatasan yang ada pada peneliti terutama keterbatasan waktu yang hanya 10 hari dalam melakukan penelitian, keterbatasan tenaga (jumlah peneliti yang hanya 1-2 orang perlokasi) dan pembiayaan (yang sudah ditentukan oleh Dipa), maka penelitian hanya difokuskan pada aspek penyelenggaraan madrasah di daerah minoritas muslim, mencakup hal-hal sebagaimana telah diuraikan di atas.

\section{HASIL DAN PEMBAHASAN}

\section{Gambaran Umum Kabupaten Manokwari $^{30}$}

Kabupaten Manokwari yang ada di Propinsi Papua Barat memiliki luas wilayah

${ }^{30}$ Data tentang gmbaran umum Kabupaten Manokwari diperoleh dari buku statistik "Manokwari dalam Angka" tahun 2012 yang diperoleh dari BPS dan berdasarkan wawancara dengan kepala MIN Aimasi dan MTs Prafi (Ranti dan Sukamto ) pada hari Kamis tanggal 24 April 2014 dan kepala MI, MTs, MA Hidayatullah (Nurdin Alimudin, Rusdan, Ahmad 
14.448,50 $\mathrm{KM}^{2}$, dengan jumlah penduduk sebanyak201.936jiwayangterdiridari106.436 jiwa laki-laki dan 95.500 jiwa perempuan, yang tersebar di 29 distrik (Distrik Ransiki, Momi Waren, Nenei, Sururey, Tahota, Didohu, Dataran Isim, Anggi, Taige, Anggi Gida, Membey, Oransbari, Warmare, Prafi, Menyambow, Hingk, Catubouw, Manokwari Barat, Manokwari Timur, Manokwari Utara, Manokwari Selatan, Testega, Tanah Rubuh, Kebar, Senopi, Amberbaken, Mubrani, Masni dan Sidey.). Penelitian ini dilakukan di tiga Distrik yaitu Distrik Prafi, Masni dan Manokwari Selatan.

Dengan melihat pada luas wilayah dan dibandingkan dengan jumlah penduduk tersebut, Kabupaten Manokwari memiliki kepadatan penduduk sebanyak 13,98 jiwa per $\mathrm{KM}^{2}$. Jumlah penduduk menurut agama dibagi menjadi lima kelompok yaitu penduduk beragama Kristen Protestan sebanyak 130.652 jiwa (64,70\%), penduduk beragama Katolik 9.935 jiwa (4,92\%), penduduk beragama Islam 60.419 jiwa (29,92\%), penduduk beragama Hindu 687 jiwa (0,3\%), penduduk beragama Budha 168 jiwa $(0,08 \%)$ dan sisanya sebanyak 74 jiwa (0,04\%) tidak diketahui agamanya.

Dilihat dari kondisi ekonominya, masyarakat Kabupaten Manokwari berada pada status sosial menengah ${ }^{31}$ ke bawah. Masyarakat dengan status ekonomi lebih baik didominasi oleh masyarakat pendatang seperti dari Makasar, Ambon, Jawa, Lombok dan lainnya. Mereka menguasai sentrasentra ekonomi pada sektor perdagangan

Sodri, Hasanudin Ali) pada hari Rabu tanggal 23 April 2014

31 Kelompok masyarakat yang baru mampu memenuhi kebutuhan pokok (primer) saja. dan pertanian/perkebunan. Sementara penduduk asli Manokwari yang merupakan suku Arfak nampak terpinggirkan/ termarginalkan baik dalam hal ekonomi, pemukiman, pendidikan maupun status sosial lainnya. Mereka umumnya tinggal di lereng-lereng gunung dan hanya mengandalkan hasil hutan sebagai mata pencahariannya. Menurut Syamsudin (pengawas madrasah yang merupakan penduduk asli Papua dari Sorong) dan Sukamto (kepala MTsN Prafi) mengatakan bahwa, mereka terkenal sangat malas dan suka mabok-mabokan, tidak memiliki masa depan dan tidak mau berpikir tentang masa depan. Mereka hanya mampu berpikir apa yang bisa dimakan hari ini. Sehingga seberapapun uang yang mereka peroleh akan segera habis hanya digunakan untuk foya-foya, mabok-mabokan dan untuk makan hari ini.

Lebih lanjut menurut keduanya, seorang kepala suku memiliki penghasilan yang sangat besar yang berasal dari upeti yang diberikan oleh PT Metco dan PT Musirawa (sebuah perusahaan pengolah kelapa sawit) yang masing-masing memberikan upeti sebesar Rp. 150.000.000,- pertahunnya, upeti dari masyarakat setiap kali habis panen yang besarannya mereka (suku penduduk asli) yang menentukan, upeti dari pengambilan pasir di pantai sebesar Rp. 150.000,- tiap satu truk, upeti membuka palang bila terjadi peristiwa kecelakaan dan mengakibatkan meninggalnya suku penduduk asli yang besarnya mencapai milyaran rupiah dan upeti-upeti lainnya. Namun dengan penghasilan yang sangat besar tersebut tetap membuat mereka miskin dan tidak memiliki harta benda, bahkan untuk makan sehari-haripun sangat sulit. Karena setiap 
memperoleh penghasilan sebesar apapun, langsung digunakan untuk pesta/foyafoya dan mabuk-mabukan, untuk kawin lagi, dan tidak pernah menyisakan untuk kepentingan hari esuk dan masa depan anak-anak mereka.

Dilihat dari kondisi sosial budaya, kehidupan masyarakat Manokwari diwarnai oleh keanekaragaman suku/ etnis pendatanag. Budaya-budaya yang berkembang di masyarakat tersebut seperti bahasa, adat istiadat, kebiasaan, tata cara berperilaku dan sebagainya, banyak diwarnai oleh adat yang dibawa oleh masingmasing suku termasuk suku pendatang. Di pemukiman suku Jawa (di 11 SPT) misalnya, bahasa yang digunakan seharihari adalah bahasa jawa, adat kebiasaan yang berkembang juga adat jawa seperti adat perkawinan, kelahiran, kematian, kesopan santunan, adat berperilaku dan sebagainya. Begitu juga di pemukiman suku Bugis yang ada di sepanjang pantai di daerah perkotaan, budaya yang berkembang juga budaya bugis. Sedangkan bagi penduduk asli suku Arfak, menerapkan adat budaya yang mereka bangun sendiri, namun masyarakat pendatang/migran juga terkena dampak aturan-aruran adat yang berlaku bagi mereka, seperti adanya upeti, denda buka palang, ijin mendirikan bangunan dan lainnya.

Dilihat dari kondisi politik, masyarakat Manokwari menyalurkan aspirasinya melalui 12 partai politik yaitu Partai Hanura, PBN, PKS, PAN, PDIP, P3, Golkar, Partai Pemuda Indonesia, Partai Demokrasi Kebangsaan, Partai Pelopor, Partai Patriot dan Partai Demokrat. Dari 12 partai tersebut, PDIP dan PAN memiliki perwakilan di DPRD paling banyak yakni masing-masing 6 orang, disusul Golkar 3 orang, Partai demokrat 2 orang dan lainnya satu orang. Dari 12 partai tersebut, partai Islam hanya diwakili oleh dua partai yaitu PKS dan P3. Sementara dari 25 orang anggota DPRD, perwakilan umat Islam hanya 5 orang atau sekitar $20 \%{ }^{32}$ Sedikitnya jumlah keterwakilan elemen Islam di DPRD ini, menjadikan perjuangan umat Islam dalam menegakkan panji-panji Islam seperti pendirian rumah Ibadah (masjid dan musala), penyelenggaraan pendidikan Islam dsb, sangat berat dan menemui banyak kendala, karena terganjal oleh kebijakan yang kurang berpihak.

\section{Sejarah Pendirian Madrasah ${ }^{33}$}

Di kabupaten Manokwari terdapat tujuh madrasah yaitu 3 MI; 2 MTs dan 2 MA. Ketujuh madrasah tersebut adalah MI, MTs, MA Hidayatullah; dan MIN, MTsN, MAN Prafi serta MIN Masni. Dilihat dari sejarah pendiriannya, kehadiran madrasah di Kabupaten Manokwari seluruhnya diawali dengan proses migrasi (perpindahan penduduk) baik perseorangan karena tujuan tertentu maupun secara kelompok melalui proses transmigrasi. Sehingga dapat dikatakan bahwa madrasah di Manokwari identiksebagailembagapendidikanmasyarakat

${ }^{32}$ Badan Pusat statistik Kabupaten Manokwari, 2012, "Manokwari dalam Angka".

33 Data tentang sejarah pendirian madrasah yang ada di Kabupaten Manokwari dan aspek-aspek yang melingkupinya, diperoleh dari wawancara dengan pengurus yayasan, kepala MIN Aimasi dan kepala MTsN Prafi (Abdul Kholik Bukhori, Ranti, dan Sukamto) dan wawancara dengan pengurus yayasan, kepala MI, MTs, MA Hidayatullah (Nurdin Alimudin, Rusdan, Ahmad Sodri, Hasanudin Ali) pada hari Rabu dan Kamis tanggal 23-24 April 2014; dari dokumen yang diberiken ketiga jenjang madrasah tersebut dan dari Seksi Mapenda Kemenag Kab. Manokwari. 
migran (masyarakat pendatang), karena didukung (didirikan, dikelola dan diminati) oleh masyarakat migran/pendatang. Dari tujuh madrasah yang ada, tiga madrasah yaitu MI, MTs dan MA Hidayatullah didukung oleh masyarakat migran dari Makasar, yang datang ke Manokwari karena mengemban misi Syi'ar Islam yang dikirim oleh Pondok Pesantren Hidayatullah pusat di Balikpapan dan karena tujuan tertentu misalnya berdagang. Sementara empat madrasah yaitu MIN Prafi, MIN Masni, MTsN Prafi dan MAN Prafi didukung oleh masyarakat dari Jawa, yang datang ke Manokwari melalui program transmigrasi.

\section{MI, MTs, MA Hidayatullah}

Pendirian MI, MTs dan MA Hidayatullah, dilatarbelakangi oleh adanya visi Pondok Pesantren Hidayatullah untuk menegakkan peradapan dan syari'at Islam di seluruh kabupaten yang ada di Indonesia melalui misi pendirian lembaga pendidikan Islam formal semisal madrasah. Pendirian madrasah dipandang sebagai upaya paling efektif dalam menegakkan peradaban dan syari'at Islam, karena penyampaian materi agama Islam kepada anak didik lebih mudah, dapat menyampaikan materi yang lebih luas, lengkap dan tersetruktur, sehingga visi dan misi institusi dapat terwujud. Pondok Pesantren Hidayatullah pusat memiliki program yang terbagi dalam tiga bidang yaitu bidang pendidikan Islam, sosial dan keagamaan. Di bidang pendidikan, memiliki program untuk menyelenggarakan pendidikan Islam formal di seluruh kabupaten yang ada di Indonesia minimal satu lembaga pendidikan dalam satu kabupaten. Manokwari, menjadi salah satu sasaran pengembangan lembaga pendidikan Islam tersebut, karena disamping merupakan daerah minoritas muslim, jumlah madrasah daerah ini juga masih sedikit. Atas dasar alasan tersebut, maka pada tahun 1992, didirikan Madrasah Ibtidaiyah Hidayatullah (MIH) di tanah wakaf seluas 4 hektar dari H. Arsyad (seorang kaya yang mukim di Manokwari). Sedangkan pada tahun 2007 didirikan Madrasah Tsnawiyah Hidayatullah (MTsH) dan pada tahun 2010 didirikan Madrasah Aliyah Hidayatullah (MAH), serta tahun berikutnya didirikan TK al-Hijrah dan PAUD al-Hidayah. Pendirian madrasah ini didukung oleh masyarakat baik secara moril maupun materiil. Masyarakat pendukung madrasah Hidayatullah ini mrupakan masyarkat pendatang tapi bukan masyarakat transmigrasi.

Jumlah peserta didik yang belajar di madrasah Hidayatullah Manokwari mulai dari jenjang PAUD hingga MA sebanyak 300 orang yang terdiri dari 30 orang peserta didik PAUD dan TK, 123 orang peserta didik MI, 77 orang peserta didik MTs dan 70 orang peserta didik MA. Mereka berasal dari berbagai daerah seperti Sulawesi Selatan, Jawa Tengah, Jawa Timur, Kalimantan Timur, dari Papua Barat seperti dari Kabupaten Fak-fak, Raja Ampat, Sorong, Kaimana, Teluk Bintuni, Manokwari dan sebagian dari Merauke. Seluruh peserta didik yang belajar di MI, MTs dan MA Hidayatullah tidak dikenakan biaya alias gratis. Karena mereka umumnya merupakan anak yatim, fakir miskin dan anak terlantar, yang sengaja direkrut untuk dipelihara dan disantuni, dididik dan diajarkan tentang ilmu pengetahuan dan agama, agar mereka menjadi anak-anak yang mengerti tentang syari'at Islam. 
Sebagai institusi pengelola madrasah, peran Hidayatullah sangat kental mewarnai madrasah mulai dari penyelenggaraan pendidikan, pembiayaan, pengelolaan hingga penetapan kurikulum. Dalam penyelenggaraan kurikulum, Hidayatullah menetapkan satu mata pelajaran agama yang wajib diajarkan di madrasah yaitu Sistematika Nuzulnya Wahyu (SNW). Mata pelajaran ini mengajarkan materi tentang pemahaman terhadap beberapa surat dalam al-Qur'an yaitu: 1) pemahaman surat al-'Alaq untuk mengajarkan materi pendidikan; 2) pemahaman surat alQalam untuk mengajarkan idiologi dan ketauhidan; 3) pemahaman surat alMuzammil untuk mengajarkan ibadah; dan 4) pemahaman surat al-Mudatsir untuk mengajarkan tentang kemasyarakatan dan keorganisasian.

\section{MIN Aimasi, MTsN dan MAN Prafi}

Pendirian MIN Aimasi, MTsN dan MAN Prafi dan MIN Masni, memiliki latar belakang yang hampir sama yakni adanya kebutuhan masyarakat transmigrasi terhadap layanan pendidikan agama yang lebih lengkap dan terstruktur, yang tidak dapat terpenuhi bila anak-anak mereka sekolah di sekolah umum (SD, SMP, SMA) yang lokasinya jauh dari Distrik Prafi, karena di sekolah tersebut tidak memiliki GPAI. Sementara jika mereka belajar di musala atau masjid, pendidikan agama Islam yang diperoleh tidak maksimal dan kurang terstruktur, karena kondisi pendidik atau ustaz yang mengajar kurang kompeten. Alasan lainnya, di distrik Prafi saat itu belum terdapat lembaga pendidikan formal. Gagasan/ide pendirian madrasah ini muncul dari tokoh masyarakat bernama Abdul Kholik Bukhori (asal Kudus Jateng).
Menurutnya, akan lebih efisien kalau di Satuan Pemukimannya (SP) 3 terdapat lembaga pendidikan Islam formal berbentuk madrasah, sehingga disamping anakanak bisa memperoleh pendidikan formal sekaligus memperoleh pendidikan agama.

MasyarakatPrafimerupakan masyarakat pendatang (transmigrasi dari pulau Jawa) tahun 70 an dan awal tahun 80 an. Di daerah ini terdapat tiga distrik/kecamatan dan 11 SP. Pada awalnya satu SP berjumlah sekitar 300-350 KK, namun mulai tahun 2010 diperkirakan satu SP berjumalah lebih dari 500 KK. Jika satu KK dirata-rata berjumlah 4 jiwa, maka jumlah penduduk seluruhnya sekitar 22.000 jiwa lebih. Pada awal tahun 90 an, Abdul Kholik bertemu dengan tokoh al-Khoirot Syagaf al-Jufni, cucu dari Habib Salim Idrus al-Jufni (pendiri al-Khoirot Palu) dan H. Kisman Adam (tokoh al-Khoirot di Manokwari). Melalui ketiga tokoh tersebut, kemudian didirikan MI al-Khoirot tahun 1991, MTs al-Khoirot tahun 1996 dan tahun 2009 didirikan MAN Prafi oleh Kemenag yang membuka jurusan IPA dan agama dan memiliki jumlah peserta didik 165 orang.

Madrasah didirikan diatas tanah seluas $5000 \mathrm{M}^{2}(100 \times 50)$ pemberian dari Departemen Transmigrasi. Sedangkan untuk membangun gedung, didukung penuh oleh masyarakat dalam bentuk sumbangan tenaga, pikiran, iuran rutin, infak, sedekah dan juga didukung pemerintah (Camat Warmare bernama Kapisa) dalam bentuk dukungan moril yang menjadikan dirinya sebagai jaminan kelancaran pendirian madrasah. Dukungan juga diberikan dari TNI angkatan laut yang dipimpin Letkol Herman Winarno 1 dari Jogja, bersama anak buahnya setiap hari minggu selalu datang menyumbangkan tenaganya dan meminta 
kepada kepala suku/ketua adat untuk menyumbangkan pasir dan batu.

Pada tahun 2003 MTs al-Khoirot di negerikan dan berubah nama menjadi MTsN Prafi dan tahun 2010 MI al-Khoirot juga di negerikan dan berubah nama menjadi MIN Aimasi. Pasca dinegerikan, input peserta didik naik cukup fantastik karena ternyata masyarakat sangat menginginkan adanya sekolah negeri. Saat ini MTN Aimasi memiliki jumlah siswa sebanyak 214 orang dan MTsN Prafi memiliki jumlah siswa sebanyak 285 orang. Sedangkan MIN Masni didirikan tahun 2000 dan dinegerikan tahun 2003. Saat ini MIN Masni telah memiliki 9 lokal belajar untuk 9 rombel (kelas 2, 3, 4 memiliki 2 rombel), 1 lokal kantor pendidik, ruang untuk kepala madrasah dan laboratorium. Adapun jumlah siswa yang dimiliki sebanyak 186 orang.

\section{Kondisi Delapan Komponen Madrasah ${ }^{34}$}

Kondisi seluruh madrasah (MI Ya Bunayya Hidayatullah, MTs Lukmanul Hakim Hidayatullah, MA Integral Hidayatullah, MIN Aimasi Prafi, MTsN Prafi, MAN Prafi dan MIN Masni) dilihat dari tingkat keterpenuhannya terhadap Standar Nasional Pendidikan (SNP) pada delapan komponen pendidikan seperti sarana prasarana, pendidik dan tenaga kependidikan, peserta didik, pembiayaan,

${ }^{34}$ Data tentang delapan komponen madrasah yang ada di Kabupaten Manokwari dan aspekaspek yang melingkupinya, diperoleh berdasarkan pengisian instrumen, wawancara dengan pengurus yayasan, kepala dan guru madrasah, dengan Kasi Mapenda kemenag Kabupaten Manokwari, yang dilakukan pada hari Rabu - Senin tanggal 23 - 29 April 2014, dan dari pengamatan yang dilakukan peneliti serta dari dokumen yang diberiken dari madrasah tersebut serta dokumen dari Seksi Mapenda Kemenag Kabupaten Manokwari. kurikulum, proses pembelajaran dan kompetensi lulusan, belum memenuhi SNP.

Kondisi Madrasah (MI, MTs, MA Hidayatullah) yang memiliki lahan sangat luas, namun belum ditunjang dengan keberdaan sarana gedung sekolah yang memadahi, seperti kondisi bangunan gedung madrasah yang kurang bagus, belum dilengkapi ruang kantor (untuk kepala, pendidik dan tenaga kependidikan) dan ruang laboratorium, belum memiliki ruang multimedia, ruang UKS, ruang OSIS, ruang BK dan ruang keterampilan. Madrasah juga belum didukung prasarana pembelajaran yang lengkap seperti koleksi buku perpustakaan dan peralatan laboratorium yang terbatas jenis dan jumlahnya. Pada komponen pendidik kondisinya hampi sama yakni jumlah pendidik terbatas, kualifikasi dan kompetensinya belum memenuhi SNP. Sedangkan pada komponen pembiayaan, ketiga madrasah tersebut tidak memiliki sumber pembiayaan tetap, dan hanya mengandalkan BOS dan donatur dari masyarakat. Menurut para kepala madrasah (MI, MTs, MA), biaya operasional pendidikan di madrasah baru terpenuhi sekitar 50\% dari kebutuhan yang seharusnya. Begitu juga pada komponen proses, pelaksanaan pembelajaran belum dapat berjalan maksimal, karena tidak ditunjang oleh sarana pembelajaran yang lengkap dan tenaga pendidik yang kompeten, sehingga hasil pembelajaran/output peserta didik juga kurang maksimal dengan rata-rata nilai UN tiga tahun terakhir masih di bawah 7.

Kondisi madrasah (MIN Aimasi, MTsN, MAN Prafi dan MIN Masni) yang berada pada Satuan Pemukiman Transmigrasi (SPT) sedikit lebih baik, karena madrasahmadrasah ini merupakan madrasah negeri 
yang memperoleh support pendanaan dari pemerintah. Namun demikian dilihat dari tingkat pemenuhannya terhadap SNP, juga belum memenuhi SNP secara maksimal. Pada standar sarana prasarana, umumnya madrasah memiliki gedung yang agak baik dengan jumlah ruang kelas sesuai jumlah rombel dan sudah dilengkapi dengan laboratorium dan perpustakaan. Pada komponen pendidik, seluruh pendidik berpendidikan S1 dan tidak ada yang mismatch. Pada komponen pembiayaan, memiliki sumber pembiayaan rutin dari DIPA, namun jumlahnya belum mencukupi seluruh kebutuhan madrasah. Sedangkan pada komponen proses, pelaksanaan pembelajaran belum berjalan maksimal, karena belum ditunjang prasarana multimedia seperti hotspot area, LCD, big screen, laptop, CD, VCD dan sebagainya, sehingga output peserta dididk juga masih kurang maksimal dan rata-rata nilai UN tiga tahun terakhir masih di bawah 7,5.

Titik lemah pada madrasah-madrasah yang ada di SPT ini adalah terletak pada minimnya sarana penunjang pembelajaran yang lebih modern sebagaimana diuraikan, dan diversifikasi metode pembelajaran yang belum banyak diterapkan oleh para pendidik. Menurut para pendidik, untuk dapat meneapkan diversifikasi metode pembelajaran dibutuhkan bantuan saana pembelajaranyanglebihlengkapdanmodern dan support pendanaan yang mencukupi. Sementara meskipun memperoleh anggaran dari DIPA, keberadaan anggaran tersebut belum mampu mencukupi seluruh kebutuhan operasional madrasah terutama untuk pengembangan proses pembelajaran. Menurut kepala MI Ranti, sering terjadi penerimaan anggaran yang tidak sesuai dengan kebutuhan yang diusulkan, sehingga persoalan-persoalan yang ada di madrasah lambat penyelesaiannya.

\section{Kebijakan Pemerintah}

\section{Kebijakan Kemenag 35}

Kantor Wilayah Kementerian Agama (Kanwil Kemenag) Propinsi Papua Barat selaku instansi pemerintah di daerah yang menaungi madrasah, memiliki beberapa program dalam penyelenggaraan madrasah. Beberapa program tersebut, menurut Miftah (Kepala Seksi Sarana Prasarana Bidang Pendidikan Islam Kanwil Kemenag Propinsi Papua Barat), umumnya merupakan Rencana Kinerja Program Pusat (RKPP). Sebagai intansi pemerintah yang tidak diotonomikan, Kemenag di daerah dalam menjalankan tugas dan fungsinya mengacu pada RKPP yang disusun oleh Kemenag Pusat. Beberapa program tersebut meliputi pengembangan sarana prasarana, pengembangan ketenagaan, pengembangan kurikulum, dan pengembangan proses pembelajaran. Program pengembangan sarana prasarana madrasah dilakukan dengan mengacu pada tiga hal yaitu program pengadaan Ruang Kelas baru (RKB), program rehabilitasi gedung (Rusak Berat (RB) dan Rusak Ringan (RR)) dan program pengadaan prasarana pembelajaran. Untuk rehabilitasi

${ }^{35}$ Data tentang kebijakan Kemenag Kabupaten Manokwari, diperoleh dari wawancara dengan Kasi Sarana Prasarana (Miftah) dan Kasi Kurikulum (Ratmini) Bidang Mapenda Kanwil Kemenag Propinsi Papua Barat dan Kasi Mapenda Kemenag Kabupaten Manokwari (Andi Aminah), yang dilakukan pada hari Rabu - Jumat tanggal 23 - 25 April 2014, dan dari dokumen yang diberikan dari Bidang Mapenda Kanwil Kemenag serta dokumen dari Seksi Mapenda Kemenag Kabupaten Manokwari. 
rusak ringan, besar anggaran Rp.65.000.000,per-satuan, sedangkan untuk rehabilitasi rusak berat, besaran anggaran antara $\mathrm{Rp}$. 80.000 .000 ,- hingga Rp. 100.000.000,- persatuan. Gedung yang rusaknya parah, diberikan anggaran Rp. 80.000.000,-, lebih dan yang rusak berat namun tidak parah, diberikan anggaran Rp. 80.000.000,-.

Program pengembangan ketenagaan, ditujukan untuk meningkatkan kualifikasi, kompetensi dan kesejahteraan pendidik dan tenaga kependidikan. Untuk meningkatkan kualifikasi dan kompetensi, dilakukan melalui diklat, orientasi, workshop, seminar, bimtek dan sosialisasi. Pada tahun 2012, Kemenag memiliki program workshop KTSP untuk tingkat MI dengan anggaran sebesar Rp. 180.305.000,- dan untuk tingkat MTs sebesar 186.620.000,-. Pada tahun 2013, ada program sosialisasi kurikulum 2013 dengan jumlah anggaran Rp. 300.000.000,- dan bimtek dengan anggaran Rp. 399.000.000,- Tahun 2014, program bimtek dengan anggaran Rp. 363.876.000,-. Dari jumlah pendidik sebanyak 167 orang (43 orang guru MA, 50 orang guru MTs, 74 orang guru MI), yang telah mengikuti bimtek sebanyak 59 orang (14 guru MA, 17 guru MTs, 28 guru MI) dan yang belum sebanyak 108 orang (29 guru MA, 33 guru MTs, 46 guru MI). Tahun 2013 dan 2014, Kemenag memiliki program pengembangan kurikulum madrasah dengan anggaran Rp. 150.000.000,- dan beberapa kegiatan pengembangan kurikulum dengan memanfaatkan FKG/KKG/MGMP madrasah dengan anggaran Rp. 48.852.000. Untuk peningkatan kesejahteraan, dilakukan melalui percepatan pengurusan sertifikasi bagi pendidik dan pengadaan honor pendidik non PNS. Hingga tahun 2014, yang telah tersertifikasi sebanyak 55 orang (33\%).
Faktor penyebab masih banyaknya pendidik yang belum tersertifikasi antara lain karena jumlah jam mengajar tidak mencapai 24 jampel,waktu mengajar belum lama, belum berijasah sarjana.

Program pengembangan proses pembelajaran dilakukan melalui penambahan jumlah pendidik, peningkatan kualifikasi melalui diklat, workshop, dan seminr, peningkatan sarana prasarana pembelajaran, penyediaan prasarana/ alat belajar seperti buku, peralatan laboratorium, komputer, dan pengembangan kurikulum dengan memanfaatkan FKG/KKG/MGMP.

\section{Kebijakan Pemerintah Daerah ${ }^{36}$}

PemerintahDaerahmelalui Dinas Dikbud setiap tahunnya mengeluarkan anggaran yang cukup besar untuk penyelenggaraan pendidikan. Menurut Ruspita (Kepala Bidang Pendidikan Menengah Atas) dan Supaat (Kasi Kurikulum Bidang Pendidikan Menengah Pertama), anggaran tersebut dikeluarkan dalam bentuk bantuan sarana prasarana pendidikan, rehab gedung, pengadaan $\mathrm{RKB}$, insentif guru PNS, BOP/ Bosda, pengadaan guru bantu honorer dan pengadaan seragam bagi peserta didik. Bantuan tersebut bersifat tidak mengikat, artinya meskipun ini merupakan program penganggaran Pemda, namun jenis-jenis bantuan tersebut tidak wajib ada setiap tahunnya. Mengenai total besaran anggaran

36 Data tentang kebijakan Dikbud/Pemda Kabupaten Manokwari, diperoleh dari wawancara dengan Kepala Bidang Pendidikan Menengah Atas dan Kasi Kurikulum Bidang Pendidikan Menengah Pertama Dinas Dikbud Kabupaten Manokwari (Rospita dan Supaat), yang dilakukan pada hari Senin tanggal 29 April 2014, dan dengan beberapa kepala dan guru madrasah. 
untuk pendidikan, Rospita dan Supaat mengatakan tidak tahu persis (peneliti tidak tahu apakah ini jawaban sesungguhnya atau jawaban politis). Besarnya anggaran untuk pengembangan sarana prasarana pendidikan persatuan lembaga pendidikan sekitar Rp. 120.000.000,-. Anggaran untuk insentif guru PNS sebesar Rp. 600.000,- pertahun perguru dan sudah ada sejak tahun 2011. Anggaran untuk Bosda sebesar Rp. 60.000,- per peserta didik pertahun dan sudah ada sejak tahun 2014. Anggaran pengadaan honor guru non PNS sebesar Rp. 400.000,- perguru perbulan.

Menurut Ruspita dan Supaat, perlakuan Pemda/Dinas Dikbud terhadap semua satuan pendidikan tidak dibedakan, meskipun dalam kenyataan dibedakan. Bagi sekolah umum, seluruhnya memperoleh bantuan dengan jumlah dan besaran sesuai kebutuhan, sedangkan untuk madrasah, belum seluruhnya memperoleh bantuan. Madrasah yang pernah menerima bantuan insentif guru PNS baru 5 madrasah yaitu MIN Masni, MIN Aimasi, MTsN Prafi, MAN Prafi dan MTs Hidayatullah, menerima bantuan sekali tahun 2012. Madrasah juga baru menerima bantuan BOP/Bosda sekali tahun 2012 dan jumlahnya tidak sesuai dengan jumlah peserta didik. MAN dan MTsN Prafi hanya menerima bantuan Rp. 2.000.000,, MIN Aimasi dan MIN Masni menerima Rp. 3.000.000,- dan MTs Hidayatullah menerima Rp. 600.000,-. Padahal tolok ukur penghitungan anggaran Bosda adalah jumlah peserta didik dikalikan besaran anggaran. Dengan besaran bantuan Rp. 60.000 ,- per-peserta didik pertahun, maka untuk MTs Prafi yang memiliki peserta didik 285 orang, seharusnya memperoleh Bosda sebesar Rp. 17.100.000,-; MTs Hidayatullah yang memiliki peserta didik 102, seharusnya menerima Bosda Rp. 60.120.000,-. Begitu juga bantuan rehab lokal, baru MI dan MTs Hiday atullah yang pernah menerima bantuan sekali pada tahun 2011 sebanyak 3 lokal untuk masing-masing madrasah dengan nilai bantuan perlokalnya Rp. 65.000.000,-. Untuk bantuan tenaga pendidik non PNS, baru MIN Masni yang pernah menerima sekali sebanyak 2 orang guru. Sedangkan bantuan seragam MTsN Prafi pernah memperoleh bantuan dua kali tahun 2011 dan 2013. Bantuan komputer, MIN Aimasi pernah menerima 15 unit tahun 2014 melalui pengajuan ke Dinas Dikbud.

\section{Kebijakan DPRD ${ }^{37}$}

Kebijakan DPRD Kabupaten Manokwari tehadap penyelenggaraan pendidikan Islam termasuk madrasah, belum dapat dilakukan secara maksimal. Kondisi mayoritas-minoritas pemeluk agama, berpengaruh besar terhadap keterwakilan elemen-elemen yang duduk dalam kursi anggota Dewan Perwakilan Rakyat (DPRD) Manokwari khususnya komisi 8 bidang pendidikan. Dari 30 orang yang duduk pada kursi DPRD, hanya ada 5 orang yang beragama Islam (satu orang wakil dari PKS, satu orang wakil dari P3, dua orang dari PDI dan satu orang dari PAN). Kondisi yang tidak seimbang ini, menjadikan keberadaan anggota dewan dari kelompok minoritas (partai Islam) tidak memiliki power dalam setiap pengambilan kebijakan. Dampaknya kelompok minoritas (kelompok masyarakat

37 Data tentang kebijakan DPRD Kabupaten Manokwari, diperoleh dari wawancara dengan anggota DPRD Bidang Pendidikan (Imam Muslih), yang dilakukan pada hari Sabtu tanggal 27 April 2014, dan dengan beberapa kepala dan guru madrasah. 
muslim) sebagai objek kebijakan menjadi pihak yang dirugikan.

Kondisi yang demikian, menurut Imam Muslih (anggota komisi 8 bidang pendidikan DPRD perwakilan dari PKS), menjadikan para anggota dewan komisi 8 khususnya perwakilan dari partai-partai Islam tidak dapat memperjuangkan aspirasi umat Islam termasuk lembaga pendidikan Islam (madrasah) secara maksimal. Sedikitnya perwakilan dari partai Islam ini, sehingga selalu mendapat perlawanan keras oleh anggota dewan lain yang non Islam dalam sidang memperjuangkan kenaikan anggaran untuk lembaga pendidikan Islam semisal madrasah. Bahkan terkadang mendapatkan cemoohan dengan kata-kata yang kurang pantas, seperti "kalian datang ke Papua hanya sekedar mencari makan" jadi nggak usah banyak tuntutan. Masyarakat Papua sangat resisten terhadap keberadaan masyarakat pendatang terlebih yang beragama Islam. Untuk dapat memperjuangkan kenaikan anggaran tersebut, para anggota dewan ini melakukan pendekatan personal dengan membina hubungan baik terhadap anggota dewan non muslim yang memiliki posisi strategis di anggaran, tidak menunjukkan sikap yang agresif, dan mengikuti aturan main. Menurut Imam Muslih, cara ini dianggap paling efektif, dibanding menyuarakan secara terang-terangan melalui sidang yang resmi.

\section{Relasi dan Lingkungan Sosial Masyarakat Madrasah}

Manusia pada dasarnya merupakan makhluk sosial yang memiliki naluri untuk hidup dengan manusia lainnya. Naluri untuk hidup dengan orang lain ini disebut gregariousness, sehingga manusia disebut juga sebagai social animal (hewan sosial). ${ }^{38}$ Manusia secara individu merupakan anggota dari suatu masyrakat, sehingga ia tidak bisa melepaskan diri dari kondisi lingkungan dan kondisi sosial budaya sekitarnya, karena masing-masing memiliki kepentingan individual dan kepentingan bersama. Hubungan/interaksi sosial merupakan kunci dari kehidupan sosial, karena tanpa adanya hubungan/interaksi sosial tidak mungkin ada kehidupan bersama. Oleh karena itu dalam melakukan berbagai aktivitas, antara manusia yang satu dengan yang lain saling terkait dan membutuhkan. Namun demikian untuk daeah-daeah tertentu, sering terjadi permasalahan yang serius tekait hubungan/interaksi sosial. Pada daerah-daerah kepulauan, daerah terpencil, daerah tertinggal dan sebagainya, hubungan/interaksi sosial memiliki masalah yang serius. Menurut Onisimus, pola hidup, pandangan, dan sikap masyarakat yang ada di daerah tersebut terkadang sulit menerima sebuah perubahan, gagasan, pemikiran baru/modern dan pembangunan, karena mereka masih terikat dengan sistem, nilai, adat, dan kepercayaan yang begitu kokoh yang ada pada masyarakat tersebut. Bahkan pada kontek tertentu mereka tidak menginginkan adanya campur tangan pemerintah atau masyarakat baru, terhadap prinsip hidup yang berbeda/bertentangan dengan kultur dan budayanya. ${ }^{39}$ Untuk dapat membangun hubungan/interaksi sosial yang baik dengan masyarakat lokal, diperlukan adanya pendekatan yang

38 Soejono Soekamto. 1982. Pengantar Sosiologi, Jakarta; P.T. Raja Grafindo. h. 101

${ }^{39}$ Onimismus Amtu. 2014. Membenahi Pendidikan di Wilayah Kepulauan, Bandung: Alfabeta, h. 27 
baik dengan prinsip-prinsip yang tidak bertentangan dengan kearifan lokal. Hal ini pula yang telah dilakukan oleh pengelola madrasah yang ada di Manokwari dengan masyarakat penduduk asli.

Hubungan/interaksi sosial pengelola madrasah dengan penduduk asli yang ada di dekat SPT terlihat kurang harmonis. Masyarakat pendukung madrasah yang sebagian besar masyarakat transmigrasi dari Jawa yang jumlahnya lebih besar dari penduduk asli, tidak serta merta menguasai seluruh sendi-sendi kehidupan. Mereka tetap harus mentaati aturan hidup yang tidak tertulis yang dibangun oleh penduduk asli, yang tidak berkeadilan, seperti: 1) untuk mendirikan sekolah, musala atau masjid, mereka tetap harus mendapat ijin dari kepala suku setempat, karena tanpa adanya ijin, maka pendiriannya tidak dapat dilakukan dan bahkan bisa timbul persoalan yang dapat mengarah pada satu konflik; 2) kewajiban membayar upeti bagi masyarakat pendatang yang mengambil pasir di pantai sebesar Rp. 120.000 persatu truk; 3) pembayaran upeti sehabis panen yang besarnya mereka yang menentukan; 4) pembayaran denda yang sangat tinggi hingga milyaran rupiah bila pengendara mobil menabrak penduduk asli hingga meninggal. Sebelum denda dibayar, jalan tempat terjadinya kecelakaan tersebut akan diberi palang dengan kayu glondongan sehingga tidak bisa dilewati kendaraan, padahal jalan tersebut satu-satunya akses menuju pemukiman.

Sedangkan hubungan madrasah Hidayatullah dengan penduduk asli yang ada di sekitar madrasah tidak terlalu bermasalah. Jumlah penduduk asli yang tidak terlalu banyak yang ada di lingkungan sekitar madrasah, sehingga keberadaannya tidak terlalu berpengaruh terhadap penyelenggaraan madrasah. Penduduk asli di perkotaan terlihat sangat sedikit. Umumnya mereka tinggal agak jauh dari perkotaan seperti di lereng bukit, di hutan dan desadesa yang jauh dari perkotaan. Penduduk Papua yang ada di sekitar madrasah Hidayatullah, umumnya bukan penduduk asli Manokwari dan mereka berasal dari kabupaten lain sekitar Manokwari, sehingga secara adat mereka tidak memiliki pengaruh yang signifikan, karena mereka juga merupakan pendatang. Untuk mendirikan madrasah, tidak perlu ijin ke kepala suku sebagaimana yang terjadi di SPT. Namun aturan hidup yang lain seperti ijin pengambilan pasir, membayar denda bila terjadi kecelakaan, membayar ganti rugi tanah atas bangunan dan lain sebagainya, juga berlaku sebagaimana di SPT.

\section{Faktor Pendukung dan Penghambat}

Beberapa faktor yang mendukung penyelenggaraan madrasah di Kabupaten Manokwari antara lain semangat masyarakat khususnya masyarakat pendatang untuk berkontribusi dalam penyelenggaraan madrasah sangat tinggi; jumlah umat Islam cukup banyak sekitar 30\% dari jumlah penduduk; jumlah madrasah yang masih sedikit tidak seimbang dengan jumlah umat Islam; kebutuhan masyarakat terhadap Pendidian Agama Islam yang tidak terpenuhi melalui kegiatan keagamaan di masjid dan musala, sementara untuk memperoleh Pendidikan Agama Islam di sekolah umum sulit terpenuhi karena keberadaan GPAI yang sangat minim, bahkan sebagian besar sekolah tidak memiliki GPAI.

sedangkan faktor penghambatnya adalah kebijakan pemerintah yang belum 
berkeadilan (dokotomis) dalam memberikan perlakuan terhadap madrasah;kondisi politis yang diwarnai oleh diskriminasi mayoritas minoritas antara umat Kristen dan Islam; jumlah anggota dewan dari partai Islam yang sangat sedikit; manipulasi data yang oleh beberapa oknum, sehingga data antara umat Islam dan non Islam terlihat jomplang; belum memadahinya jumlah pendidik di madrasah baik dari segi kuantitas maupun kualitas; minimnya jumlah pendidik yang berstatus PNS; banyaknya pendidik madrasah yang mismatch; sempitnya struktur organisasi di Kemenag yang menangani madrasah.

\section{PENUTUP}

\section{Kesimpulan}

Penyelenggaraan madrasah di Kabupaten Manokwari dilatarbelakangi oleh adanya proses migrasi (perpindahan penduduk) melalui proses transmigrasi dan karena misi syiar agama Islam oleh institusi keagamaan Hidayatullah, sehingga pendirian madrasah di sana dilakukan di lokasi masyarakat migran berada yaitu di Satuan Pemukiman Transmigrasi (SPT) dan di lingkungan Pondok Pesantren Hidayatullah. Masyarakat pendukung madrasah, sepenuhnya juga merupakan masyarakat migran yang ada di dua lokasi tersebut.

Dilihat dari kondisi delapan komponen pendidikan, umumnya madrasah belum memenuhi SNP. Pada komponen sarana prasarana, seluruh madrasah baru memiliki sarana pokok seperti ruang kelas, ruang kantor (kamad, guru, TU); Pada komponen pendidik, jumlah belum memadahi; sekitar 18\% berpendidikan di bawah S1 dan 9\% mismatch. Pada komponen kurikulum, seluruh madrasah sudah menerapkan KTSP dan akan segera menerapkan kurikulum 2013. Pada komponen proses, pelaksanaan pembelajaran kurang maksimalnya sarana. Pada komponen pembiayaan, baru tercukupi sekitar 64\%, 4 madrasah memiliki sumber pembiayaan dari Dipa dan 3 madrasah tidak memiliki sumber pembiayaan tetap. Pada komponen SKL, nilai UN belum maksimal dengan nilai rata-rata UN 7,3.

Dilihat dari kebijakan pemerintah, madrasah belum memperoleh kebijakan yang berkeadilan dan masih terjadi diskriminasi kebijakan baik oleh Pemerintah Daerah, Dinas Pendidikan dan Kebudayaan maupun DPRD. Faktor politik, sosial budaya, agama dan etnis merupakan berapa faktor yang menjadi penyebab terjadinya diskriminasi kebijakan tersebut. Sedangkan kemenag sendiri belum memiliki kebijakan khusus untuk madrasah yang ada di daerah minoritas muslim. Sementara kebijakan penganggaran Kemenag masih mengacu pada kebijakan pusat melalui Rencana Kinerja Pusat (RKP) yang terkadang realisasinya tidak sesuai dengan kebutuhan daerah.

Relasi dan hubungan madrasah dengan masyarakat sekitar khususnya masyarakat pendukung (masyarakat migran) cukup baik. Mereka memberikan dukungan penuh terhadap penyelenggaraan madrasah baik secara moril maupun materiil. Namun hubungan dengan masyarakat penduduk asli, terkendala dengan aturan-aturan yang berlaku bagi penduduk asli yang juga diterapkan pada penduduk pendatang yang terkadang merugikan. Namun demikian, melalui teknik pendekatan tertentu, terkadang kendala tersebut dapat teratasi. 


\section{Saran-saran}

Mengingat banyaknya kendala yang dihadapi dalam penyelenggaraan madrasah di Kabupaten Manokwari, maka direkomendasikan kepada: pejabat Pemda Kabupaten Manokwari baik Dinas Dikbud, Pemda maupun DPRD, hendaknya mengeluarkan kebijakan yang berkeadilan dan mendukung madrasah baik dalam pembinaan maupun dalam pemberian bantuan anggaran; kepada Kemenag tingkat propinsi dan kabupaten/kota, hendaknya melakukan pendekatan dengan instansi pemerintah daerah guna memperjuangkan penganggaran bagi penyelenggaran madrasah; Kepada Kemenag tingkat pusat sebaiknya dalam menyusun RKPP mengacu pada rencana program yang diusulkan Kemenag Propinsi maupun Kabupaten/kota dan hendaknya mengalokasikan anggaran khusus bagi penyelenggaraan madrasah di daerah minoritas muslim; Kemenag tingkat pusat sebaiknya melakukan restrukturisasi melalui peluasan struktur organisasi pada Kemenag Kabupaten/Kota daerah minoritas dan mengadakan rekrutmen ketenagaan untuk madrasah dan seksi Kemenag yang mengurusi madrasah; Pusdiklat hendaknya melakukan diklat bagi pendidik madrasah daerah minoritas muslim untuk meningkatkan kompetensi dan mengurang mismatch.

\section{Ucapan Terima Kasih}

Penelitian ini dapat berjalan lancar karena adanya partisipasi/keterlibatan berbagai pihak. Oleh karena itu saya (umul Hidayati) penelitiyang melakukan penelitian ini mengucapkan terimakasih kepada:teman sesama peneliti (Sumarni) yang bersamasama melakukan penelitian di Kabupaten Manokwari; Kasi Mapenda Kemenag Kabupaten Manokwari (Andi Aminah) yang telah menerima kedatangan peneliti dan memfasilitasi kegiatan penelitian selama sepuluh hari dan telah bersedia menjadi salah satu responden dalam penelitian ini; Kasi Sarana Prasarana (Miftah) dan Kasi Kurikulum (Ratmini) Bidang Mapenda Kanwil Kemenag Propinsi Papua Barat, Para kepala dan guru madrasah serta pengurus yayasan dan komite madrasah; pengawas madrasah (Syamsudin), anggota DPRD Kabupaten Manokwari bidang pendidikan (Imam Muslih); pejabat Dinas Dikbud Kabupaten Manokwari (Rospita dan Supaat) dan semua pihak yang terlibat dan telah membantu kelancaran dalam penelitian ini yang tidak bisa disebutkan satu persatu, serta pihak-pihak yang telah bersedia menjadi responden dan memberikan sejumlah data yang dibutuhkan peneliti. 


\section{SUMBER BACAAN}

Amtu, Onimismus (2014): Membenahi Pendidikan di Wilayah Kepulauan, Bandung: Alfabeta.

Azra, Azyumardi (2002): Paradigma Baru Pendidikan Nasional (Rekontruksi dan Demokratisasi), Jakarta: Kompas.

Badan Pusat Statistik Kabupaten Manokwari (2012): Manokwari dalam Angka".

Daulay, Haidar Putra (2001): Historisitas dan Eksistensi (Pesantren,Sekolah dan Madrasah), Yogyakarta: PT. Tiara Wacana.

Freire, Paulo (2002): The Politic of Education; Culture, Power and Liberation, dalam Agung Prihantoro dan Fuad Arif Fudiyar (ed), Politik Pendidikan, Kebudayaan dan Pembebasan, Jogjakarta: Read.

Harsono (2006): Model-model Pengelolaan Perguruan Tinggi,Yogyakarta: Pustaka Pelajar.

Masykuri dkk (2005): Profil Madrasah Tsanawiyah, Jakarta: Departemen Agama RI, Direktorat Jenderal Kelembagaan Agama Islam.

Masyarakat Pendidikan (2002): Madrasah di Era Otonomi dan Globalisasi, Vol. I Nomor 5, Maret-April

Moleong, Lexy J (2002): Metode Penelitian Kualitatif, Bandung: Remaja Rosdakarya, Cet. Ke. 16

Permenag RI No. 90 Tahun 2013 tentang Penyelenggaraan Pendidikan Madrasah Bab I Pasal 1 ayat 2

Pearturan Pemerintah Nomor. 63 tahun 1992 sebagai pelaksanaan UU No. 7 Tahun 1983 tentang Pajak Penghasilan yang kemudian diubah dengan UU No. 7 Tahun 1991

Soekamto, Soejono(1992): Pengantar Sosiologi, Jakarta: P.T. Raja Grafindo.
Suaedy, Ahmad dkk (2012): Islam dan Kaum Minoritas: Tantangan Kontemporer, Jakarta: The Wakhid Institue.

Sugiono (2009): Metode Penelitian Kuantitatif Kualitatif Dan R \& D Bandung: Alfabeta.

Menteri Agama Republik Indonesia (2013): Peraturan Menteri Agama Republik Indonesia Nomor 90 Tahun 2013 tentang "Penyelenggaraan Pendidikan Madrasah".

Puslitbang Pendidikan Agama dan Keagamaan (2004): hasil penelitian berjudul "Kompetensi Kepala Madrasah Aliyah (MA)".

Puslitbang Pendidikan Agama dan Keagamaan (2005): hasil penelitian berjudul "Profil Kompetensi guru PAI MTs".

Puslitbang Pendidikan Agama dan Keagamaan (2007): hasil penelitian berjudul " Kompetensi Guru Mapel Umum (Matematika, IPA dan Bhs Ingris) MTs".

Puslitbang Pendidikan Agama dan Keagamaan (2009): hasil penelitian berjudul "Kesiapan Madrasah dalam Pemenuhan Standar Nasional Pendidikan (Standar Pengelolaan Pendidikan oleh Satuan Pendidikan, Standar Pendidik dan Tenaga Kependidikan serta Standar Sarana Prasarana) di MTsN".

Puslitbang Pendidikan Agama dan Keagamaan (2010): hasil penelitian berjudul" Pemenuhan Standar Nasional Pendidikan (Standar Proses, Isi, Penilaian dan Kompetensi Lulusan) di MTsN".

Puslitbang Pendidikan Agama dan Keagamaan (2011): hasil penelitian berjudul "Kompetensi Kepala MA".

Menteri Dalam Negeri (2006): Surat Keputusan Mendagri Nomor 903/2429/ SJ Tahun 2006 Tentang Pedoman Penyusunan APBD (untuk Pendidikan).

Tim Media, Kamus Lengkap Bahasa Indonesia, Media Center. 
Undang-Undang Nomor 20 tahun 2003 tentang Sistem Pendidikan Nasional.

Undang-Undang Nomor 22 Tahun 1999 dan revisinya Undang-Undang Nomor 32 tahun 2004 Tentang Otonomi Daerah

Yatim,Badri,dkk(2000):SejarahPerkembangan Madrasah, Jakarta: Departemen Agama RI Direktorat Jenderal Pembinaan Kelembagaan Agama Islam.

Djamaludin Djawu, dalam http://jamalmerdeka.blogspot.com/2012/10/apaitu-kaum-marjinal-marginal.html. Diunduh tanggal 8 Pebruari 2014

Syafaeny dalam makalahnya berjudul "Minoritas Muslim Dan Permasalah Mereka Dari Sudut Hukum Fiqh (Fiqh Aqalliyat)", dalam http:// syaf.blogspot.com/2012/03 / minoritas-muslim-dan-permasalahmereka. html. diunduh tanggal 10 Pebrauri 2014
Isnaini dalam http://issnaini.blogspot. com/2012/10/makalah-diskriminasipendidikan. html. diunduh tanggal 10 Pebruari 2014

Ulya Fikriyanti dalam makalahnya berjudul "Dilema kaum Minoritas: Islam Solusi Tepat" dalam http://www.academia. edu/3769057 / Kelompok-SesialMayoritas-dan- Minoritas. diunduh tanggal 10 Pebruari 2014.

http://www.academia.edu/3769057/ Kelompok-Sesial-Mayoritas-danMinoritas.diunduh tanggal 10 Pebruari 2014. 